\title{
Embryonic and uterine development during early pregnancy in pigs
}

\author{
H. W. J. Stroband and T. Van der Lende \\ Agricultural University, Departments of Experimental Animal Morphology \& Cell Biology and \\ Animal Husbandry, P.O. Box 338.6700 AH Wageningen, The Netherlands
}

\begin{abstract}
Summary. Comparison of the timing of pig preimplantation development, alterations in the ultrastructure of embryonic germ layers, and cytological changes of the uterine epithelial cells leads to the supposition that a close relationship exists between embryonic and uterine development during early pregnancy. The results of in-vitro studies of embryonic development and of experiments concerning asynchrony between embryos and uterine environment confirm this supposition, especially as far as the post-hatching period is concerned. It is suggested that successive steps in embryonic germ layer differentiation may induce specific developmental events and secretory activity of the embryos. A mutual influence of maternal and embryonic tissues appears to exist, but we can only speculate about the causes of many of the described phenomena.
\end{abstract}

Keywords: pig; embryo; uterus; ultrastructure; interaction; preimplantation development

\section{Introduction}

In the pig, as in other mammalian species, embryonic development is partly an autonomous process. Many more or less successful attempts have been undertaken to cuiture early cleavage stage embryos in vitro up to the blastocyst stage (Davis, 1985). On the other hand, many other experiments showed the necessity for synchrony in embryo transfer (Polge, 1982), illustrating a close relationship between embryonic and uterine development. During early pregnancy maternalembryonic interactions may be expected to be of special interest in the pig, since in this species, as in other domestic ungulates, the preimplantation period is prolonged.

The main objective of this paper is to review literature on morphological and histological aspects of embryonic and uterine development during early pregnancy, and to consider the facts in the perspective of interdependency. The emphasis will be on the pig, but when necessary results from other species will also be referred to.

\section{Embryo development}

\section{Pre-hatching period}

Cleavage. Only a few studies deal with the morphology (Patten, 1948; Marrable, 1971; Hunter, 1974), or the ultrastructure (Norberg, 1973a, b; Szollosi \& Hunter, 1973) of cleavage stages in the pig. Fertilization takes place in the oviduct, at the ampullary-isthmic junction. Using hCG for ovulation control, Hunter (1974) found cleaving embryos from 17 to $19 \mathrm{~h}$ after ovulation. The 2cell stage lasts for $6-8 \mathrm{~h}$; the 4 -cell stage, however, lasts for $20-24 \mathrm{~h}$ (see also Flint, 1981). As a result, the embryos are mainly in the 4-cell stage at entry into the uterus. According to Hunter (1974), embryos and unfertilized eggs enter the uterus $46-48 \mathrm{~h}$ after ovulation. However, according to Oxenreider \& Day (1965) entry into the uterus may extend over 24 h (2-3 days after ovulation). 
The 8-16-cell morula stage is reached around Day 4. In cleavage stages, cytoplasmic organelles are scarce and concentrated around the nucleus, while yolk inclusions fill up peripheral parts of the cytoplasm (Fig. 1). Mitochondria, which are globular during early cleavage stages, elongate at the morula stage, suggesting increased metabolic activity. Nucleoli are found from the 8-cell stage onwards and their development is accompanied by an increase in the number of ribosomes. This suggests activation of the embryonic genome and corresponds to the start of RNA synthesis at the 4-cell stage (Freitag et al., 1988). The 4-cell block, an obstacle in in-vitro culture, seems to be related to embryonic genome activation. It is probably analogous in this respect to the 8-16-cell block in sheep (Gandolfi \& Moor, 1987), and the 8-cell block in cows (King et al., 1988).

Differentiation of inner and outer cells (blastulation). Inner and outer cells may be distinguished in pig embryos from the 12-16-cell stage onwards. Papaioannou \& Ebert (1988) found a mean proportion of $14 \%$ inner cells in morulae, although this proportion varied widely $(0-20 \%)$. The differentiation of these cells has mainly been studied in rodents (see Prather \& First, 1988). During subsequent cleavages, the number of inner cells is determined by the pattern of cleavage of the outer cells (Johnson, 1981). According to the "inside/outside hypothesis" (see Johnson, 1981), inner cells will differentiate to the inner cell mass (ICM, the future embryo proper) while outer cells differentiate to trophectoderm. During the process of compaction, the outer cells form a layer of closely contacting polarized cells (Ducibella, 1977). Afterwards, junctional complexes, which include tight junctions and desmosomes, are formed between neighbouring cells and the trophectoderm, which is selectively permeable, is formed (Borland, 1977; McLaren \& Smith, 1977). Transport of sodium ions and water contributes to the formation of the blastocoele (Borland, 1977) and from that time onwards the conceptus is called a blastocyst. The inner cells differentiate later.

In the pig, the first signs of compaction are seen at Day 4, at the 8-cell stage (Hunter, 1974). The first junctional complexes are found at the compacted morula stage around Day 5 (Norberg, 1973a; Barends $e t$ al., 1989). This parallels embryonic development in sheep, in which only primitive junctions are present up to Day 4 (16-cell stage) and junctional complexes are found from that stage onwards between the outer cells (Calarco \& McLaren, 1976). The blastocyst stage in the pig is reached at Day 5-6 and the cell number at the moment of blastocoele formation is usually 16-32, although extremes of 9-cells up to more than 32 cells were also found (Papaioannou \& Ebert, 1988).

Pig embryos, even from Day 4, may selectively take up steroids (Stone $e t$ al., 1986) including oestrogens (Niemann \& Elsaesser, 1986), which may be related to blastulation, although Freitag et al. (1988) found no effect of an anti-oestrogen on pig blastocyst formation, in contrast to the results of Paria et al. (1984) for rabbit embryos. Other compounds, such as histamine and prostaglandins, may also influence blastocoele formation (see Prather \& First, 1988).

The ultrastructure of early pig (Norberg, 1973a; Barends et al., 1989), cow (Massip et al., 1981), sheep (Calarco \& McLaren, 1976), horse (Flood et al., 1982) and other mammalian (Enders \& Schlafke, 1965; Enders, 1971) blastocysts is generally similar. During the formation of the blastocoele, the trophectoderm celis are well developed and polarized, and bear numerous microvilli facing the uterine lumen, whilst the ICM cells are irregularly shaped, and do not show polarity (Fig. 2). In pig, the flattened trophectoderm cells contain increasing numbers of elongated mitochondria and some strands of endoplasmic reticulum and Golgi cisternae. Hardly any organelles have developed in ICM cells and both cell types still contain large yolk globules and some lipid droplets at this stage.

In the early embryonic stages of mammals, pinocytosis takes place in all blastomeres, but later in only the trophectoderm cells through their apical cell membranes. In rodents, macromolecules such as ferritin and peroxidase easily pass the zona pellucida and are taken up. In the pig, electron micrographs show coated pits and pinocytotic vesicles, but neither ferritin $(M, 160000)$, nor the smaller peroxidase molecules $\left(M_{r} 40000\right)$, pass the zona pellucida, indicating species differences in the selectivity of the zona barrier. In pig, the frequency of coated pits increases from blastocoele formation onwards. 
Before hatching, blastocysts undergo some expansion and fill the perivitelline space completely. Most embryos consist of 65-120 cells at this point, but expanded blastocysts of 17-32 cells have also been found. The proportion of inner cells reaches a maximum of $25 \%$ at this stage (Papaioannou \& Ebert, 1988).

\section{Hatching and the post-hatching period}

Hatching. Hatching from the zona pellucida occurs at Day 6-7. Papaioannou \& Ebert (1988) found no expanded blastocysts with more than 135 cells, but some hatched blastocysts consisted of only 80 cells. According to Nieman et al. (1983), the hatching process is probably independent of cell number. The factors causing zona lysis are not known but embryonic enzymes, mechanical mechanisms or uterine factors may be involved. In vitro, serum inhibits hatching in several species (Ebert \& Black, 1982); however, if albumin or fetal calf serum (FCS) is used as a protein source, hatching occurs. According to Ebert \& Black (1982), serum immunoglobulins (which are almost absent in FCS) may inhibit embryonic proteolytic activity that would have caused hatching. At the time of hatching, pig blastocysts contain prostaglandin E (Stone et al., 1986) that may be involved in regulating water transport, suggesting that mechanical mechanisms are involved, as appears to be the case for the cow (Betteridge \& Fléchon, 1988). However, in the pig the zona pellucida is not replaced by a capsule produced by trophoblast cells, as in the horse (Betteridge \& Guillomot, 1982).

Differentiation of the hypoblast and blastocyst expansion. After hatching, pig blastocysts remain free in the uterine lumen up to Day 13 (Dantzer, 1985). Other ungulates also have a prolonged preimplantation period compared to man and laboratory animals. In the latter, hatching is immediately followed by implantation unless a delay of implantation and inhibition of blastocyst growth occur as, for example, in lactating mice. The diameter of the newly hatched pig blastocyst is $\sim 0.2 \mathrm{~mm}$. Geisert et al. (1982b). Stroband et al. (1984), and Barends et al., (1989) studied the ultrastructure of hatched pig blastocysts and showed that it is very like that of other large domestic species (sheep: Wintenberger-Torrès \& Fléchon, 1974; Carnegie et al., 1985; cow: Massip et al., 1981; horse: Flood et al., 1982; Enders et al., 1988). After hatching, the first differentiation of the ICM becomes visible. In pigs, deeper cells develop filopodia and migrate along the trophoblast to form the hypoblast or (largely extraembryonic) entoderm from Day 7 onwards; these cells are flattened and show large fenestrations. They contain a swollen RER with an electron-dense content, suggesting active protein synthesis. Hypoblast cells induce the formation of a basal lamina directly beneath the trophectoderm and the remaining ICM (now called trophoblast and embryoblast respectively), and they lie at a distance from this lamina, making contact with it by filopodia. It is suggested that the hypoblast cells may also induce the formation of certain cytoskeletal elements in trophoblast cells (Albertini et al., 1987). They may also induce trophoblast hyperplasia and activate the fluid pumping mechanism, since a rapid expansion of the blastocysts to a diameter of up to $10 \mathrm{~mm}$ occurs between hatching and Day 11 (Marrable, 1971; Stroband et al., 1984, 1986). During expansion, the protein content of the pig blastocyst increases: a 15-fold increase was found between Days 8 and 9 by Wright et al. (1983). Although the secretory apparatus is well developed in trophoblast and hypoblast cells from this stage onwards, this increase in blastocyst protein is not necessarily a consequence of growth, but might partly reflect an accumulation of uterine proteins in the blastocoele. According to Beier (1985), uterine proteins are major components of rabbit blastocyst fluid during normal development in utero.

The uptake of macromolecules. Pig trophoblast cells consume their yolk shortly after hatching, indicating increased metabolism and a growing dependency on uterine substances. The zona pellucida no longer prevents certain molecules reaching the trophoblast and experiments using ferritin or peroxidase show that pig trophoblast cells easily absorb these macromolecules by means of pinocytosis (Stroband et al., 1984). These substances are transported to lysosomes (which are 

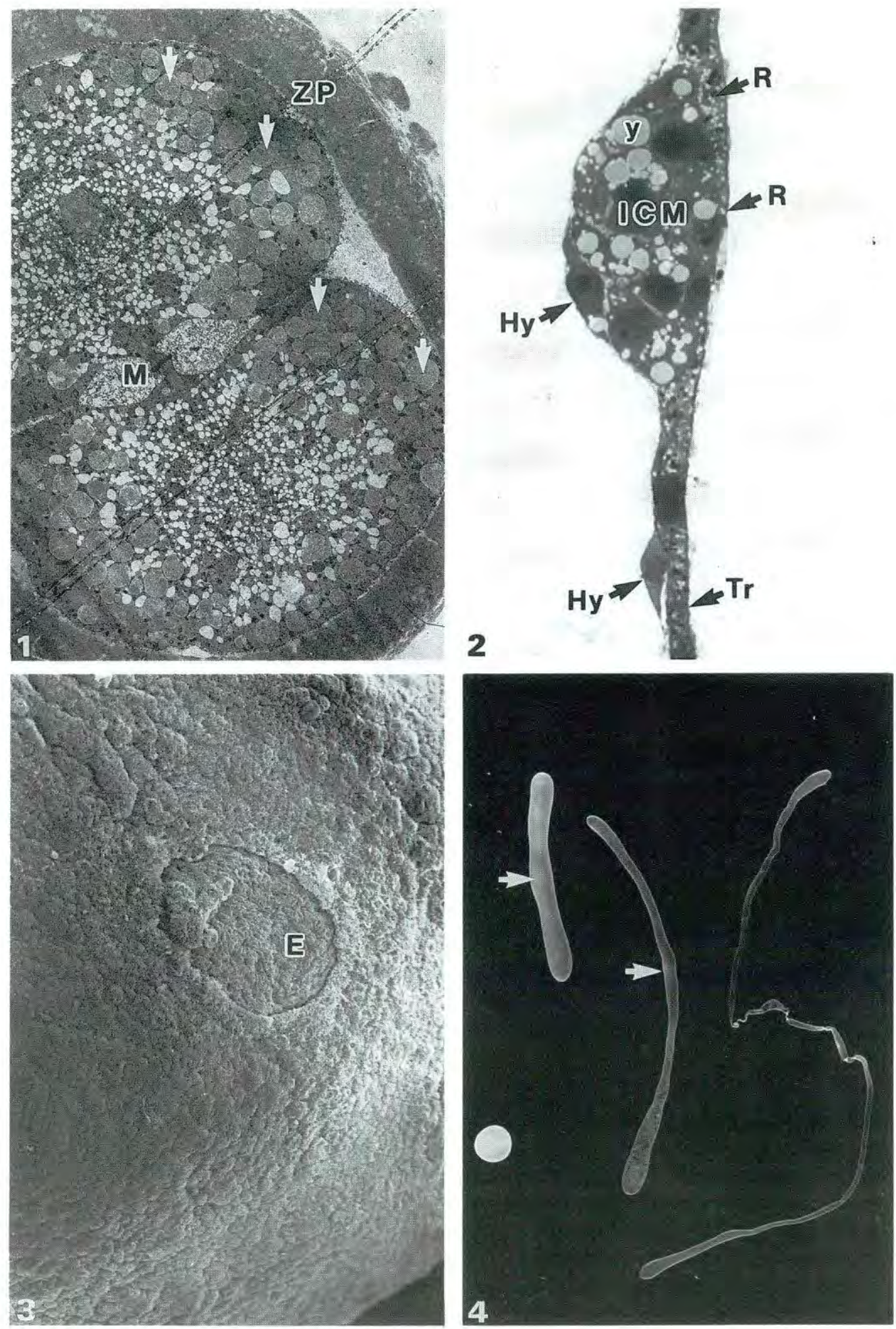
abundantly present from this stage onwards) and are digested in the apical part of the cells. However, the processing of macromolecules may be selective as Hastings \& Enders (1974) found that peroxidase, taken up by rabbit trophoblast cells, was either transported to lysosomes (and digested) or remained unaffected and was directly transported to the basal or lateral plasma membranes and expelled. According to Fleming \& Goodall (1986), macromolecules absorbed in the fluid phase are digested in the lysosomal system, while membrane-coupled uptake is also associated with transcytosis in the mouse. In trophoblast cells of other ungulates, an endocytotic as well as a lysosomal apparatus is also present, suggesting similar mechanisms for the uptake and breakdown of uterine macromolecules. Intact maternal proteins are found in the blastocoele of several mammalian species (Beier, 1985). Ferritin, injected into the pig blastocoele, is taken up by trophoblast, embryoblast and hypoblast cells (P. M. G. Barends, H. W. J. Stroband, N. Taverne, G. te Kronnie \& M. P. J. M. Leën, unpublished results), indicating that macromolecules produced by one cell type may be taken up and processed by others.

Embryoblast differentiation and loss of polar trophoblast. Until Day 10, the partly undifferentiated embryoblast is covered by polar trophoblast or Rauber cells. Just before shedding of the Rauber cells, the outer embryoblast cells lose their yolk, polarize, become interconnected by junctional complexes and develop microvilli on their future luminal surface (Barends et al., 1989). The embryonic shield so developed (epiblast or embryonic ectoderm) (Fig. 3) is therefore responsible for the maintenance of the integrity of the blastocyst, and for its ability to expand further after the rapid removal of Rauber's layer. Embryoblast cells neither absorb macromolecules from the uterine fluid nor develop an extensive lysosomal system and apparently depend on the trophoblast even after loss of Rauber's layer.

At Day 11, embryoblasts of blastocysts with a similar diameter may differ greatly in cell number (Barends et al., 1989). The size of the blastocyst and that of the embryoblast therefore appear to give different information on the developmental stage of an embryo. The diameter of a blastocyst may mainly reflect the metabolic state or viability of the trophoblast cells, while the development of the embryoblast may be a more suitable indicator for determining the stage of embryonic development.

Blastocyst elongation. From Day 11-12, pig blastocysts start elongation and reduction of their diameter, resulting in up to $100-\mathrm{cm}$ long filamentous structures. Elongation does not take place in all conceptuses at the same moment, due to variation in developmental stage (Fig. 4). Blastocyst growth may be as fast as $30-45 \mathrm{~mm} / \mathrm{h}$ and is initially the result of cellular remodelling. Later, hyperplasia occurs (Geisert et al., 1982b). From Day 12 onwards, mesoderm cells are separated from the embryoblast, in a way similar to that of the earlier hypoblast cells from the ICM (Patten,

Figs 1-4. Some aspects of pig embryonic development.

Fig. 1. Transmission electron micrograph (TEM) of 2-cell embryo, shortly after cleavage. The cells, surrounded by the zona pellucida, are connected by a midbody (M). Yolk globules (arrows) are mainly found in the periphery of the cells. The plasma membrane bears microvilli, especially around the midbody. $\times 1000$.

Fig. 2. Light micrograph (LM) of the ICM of a 7-day-old blastocyst. The ICM is covered by Rauber cells $(\mathrm{R})$, and some hypoblast cells $(\mathrm{Hy})$ have differentiated and migrated along the trophectoderm $(\mathrm{Tr}) . \times 450$.

Fig. 3. Scanning electron micrograph (SEM) of Day-10 blastocyst, showing the surface of the trophectoderm and the epiblast (E) after loss of most Rauber cells. The epiblast cells are polarized and bear microvilli. $\times 150$.

Fig. 4. Blastocysts (Day 12), flushed from one uterine horn. Arrows point to the position of the embryoblast. $\times 1.5$. 

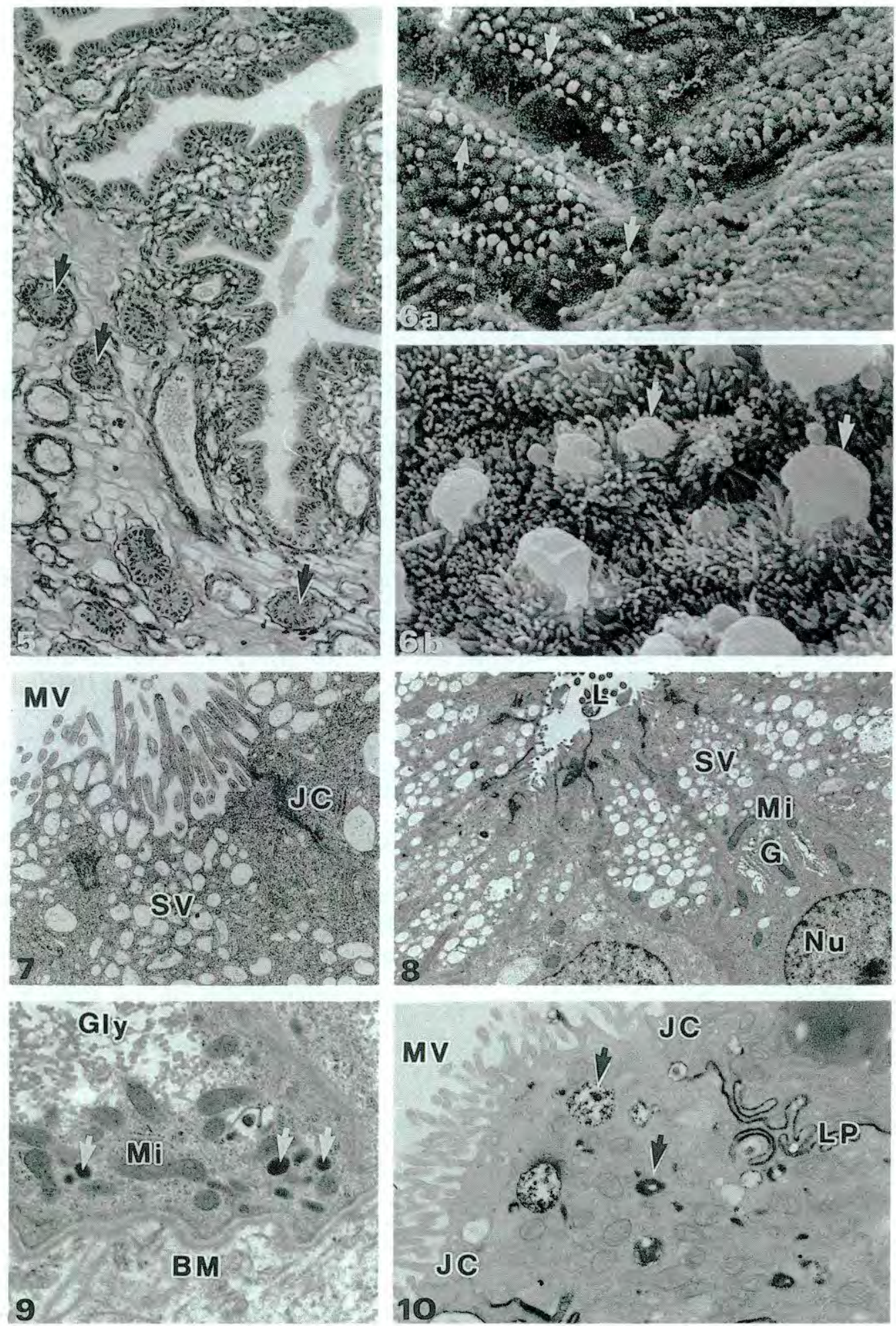
1948; Marrable, 1971; King \& Ackerley, 1985). This coincidence of elongation and mesoderm formation suggests again the influence of differentiating germ layers on trophoblast development. Fléchon et al. (1986) demonstrated the ability of sheep trophoblastic vesicles, consisting of only trophoblast and hypoblast cells, to elongate to some extent after transfer to the uterus, but the mechanism of elongation seems to differ from that in the pig, since cellular remodelling does not take place. King \& Ackerley (1985) demonstrated morphological changes in the hypoblast cells, after they had been reached by the outgrowing mesoderm. Using immunocytochemistry, these authors also demonstrated the presence of oestrogen in trophectoderm and yolk sac entoderm (hypoblast) from Day 10, with more intense localization at Days 12-16. At Day 16, a regional differentiation was found: the most oestrogen was detected in trophoblast and hypoblast cells near the embryoblast. At $20 \mathrm{~cm}$ from the embryoblast immunostaining of the trophoblast was negative. This regional differentiation corresponds with the outgrowth of mesoderm up to about $20 \mathrm{~cm}$ from the embryoblast at Day 16. According to Bate \& King (1988) all hypoblast cells produce oestrogen and the highest production occurred near the ICM, and, although somewhat lower, at the tips of the elongated embryo.

\section{Uterine development}

\section{Morphological aspects}

The uterine wall consists of the serosa, the myometrium and the endometrium. The latter consists of a tunica propria and two epithelial tissues: the luminal epithelium and the glands, which lie in the tunica propria (Fig. 5). In many models concerning embryo-maternal relationships the uterus is shown as a sac, the embryos floating more or less freely within it. However, the uterine wall is folded in such a way that opposite folds interlock and reduce the lumen to only a narrow space. During oestrus, simple folds are found but around Day 5-8 secondary and tertiary folds are formed, and these disappear again after Day 11-12 (Sidler et al., 1986; Stroband et al., 1986).

Several studies describe changes in epithelial cell height during the oestrous cycle (see Sidler et al., 1986, for review). The luminal epithelial cells reach maximum height between Days 4 and 8 , and the gland cells between Days 9 and 12. This corresponds with respective periods of increased phosphatase activity. The two cell types also show different proliferation periods (see Stroband

Figs 5-10. The uterine epithelium.

Fig. 5. Light micrograph of Chinese Meishan pig endometrium (Day 9). Note the tertiary folds in the luminal epithelium and the intense vascularization of the tunica propria, especially just beneath the epithelium. Arrows point to uterine glands. $\times 150$.

Fig. 6. Scanning electron micrograph (SEM) of luminal epithelium (Day 1). Arrows point to protrusions of some of the microvilli bearing cells. a, $\times 600 ; \mathrm{b}, \times 6000$.

Fig. 7. Transmission electron micrograph (TEM) of Day-7 luminal epithelial cells, showing microvilli (MV), junctional complexes (JC) and many secretory vesicles (SV). $\times 10000$.

Fig. 8. TEM of Day-7 glandular epithelial cells. Many secretory vesicles (SV) have been accumulated between the nucleus $(\mathrm{Nu})$ and the glandular lumen $(\mathrm{L}) . \mathrm{Mi}=$ mitochondrion; $\mathrm{G}=$ Golgi apparatus. $\times 4000$.

Fig. 9. TEM. Basal part of a Day-13 luminal epithelial cell, showing mitochondria (Mi), glycogen (Gly) and electron-dense granules (arrows) near the basement membrane (BM). $\times 35000$.

Fig. 10. TEM of Day-14 sheep luminal epithelial cell after uptake of peroxidase from the uterine lumen. Note the presence of the histochemically demonstrated enzyme within apical lysosomal structures (arrows) and smaller vesicles, but also in intercellular spaces between the lateral plasma membranes of neighbouring cells (LP). MV $=$ microvilli; JC = junctional complexes. $\times 8000$. 
et al., 1986), and immunocytochemical studies revealed that uteroferrin is mainly located in the glandular epithelium, while plasmin inhibitor is mainly restricted to luminal epithelial cells (Fazleabas et al., 1985). Obviously, luminal and glandular epithelial cells have to be considered as different populations.

\section{The ultrastructure of luminal epithelial cells}

The ultrastructure of pig preimplantation luminal epithelium has received little attention. In the combined TEM and SEM studies done by Sidler et al. (1986) and Stroband et al. (1986), the epithelium consisted of two cell types: a majority of microvilli-bearing secretory cells, and a minority of ciliated cells, especially abundant around gland openings.

From the time of oestrus, the luminal epithelium is actively secreting as yet undefined substances, as observed by TEM (Stroband et al., 1986; Sidler et al., 1986) (see Fig. 11). Oestrus-related uterine secretion also occurs in other mammalian species, including sheep and cow (Aitken, 1979). In the pig, SEM studies demonstrated groups of cells with smooth protrusions at all stages of early pregnancy, suggesting apocrine secretion (see Figs $6 a \&$ b). Similar structures were described by Aitken (1975) in roe deer uterine epithelial cells during blastocyst activation.

Many electron-lucent vesicles, irregularly shaped and $0 \cdot 1-0.5 \mu \mathrm{m}$ in diameter, accumulate in the apical part of the cells from Day 6 onwards (Fig. 7). Sometimes, these vesicles are seen to fuse with the plasma membrane, suggesting merocrine release of the product. Between Days 8 and 10 these vesicles disappear, suggesting release of their contents during this period. Similar vesicles are present in cow luminal epithelial cells and increase in number at Days 7 and 14, compared to oestrus (Hyttel, 1985), but are less abundant than in the pig. A few of the vesicles appear to be involved in endocytosis in the cow, but the majority are secretory vesicles. From Day 11 in the pig, electron-dense secretory granules are present near the basement membrane (Fig. 9), and increase in number during pregnancy, but gradually disappear after luteolysis. As a result, differences between pregnant and non-pregnant animals become visible. From Day 12, glycogen is also present in the cells, especially those of pregnant animals (Fig. 9). The above morphological evidence suggests continuous but changing secretory activity of the luminal epithelial cells.

Between Days 8 and 14, the number of tight-junction intersections between epithelial cells (a measure of permeability) increases (Johnson et al., 1988). This may have consequences for the transport of small molecules through the intercellular spaces to or from the lumen. Larger molecules appear to be transported through the epithelial cells. Selective transport in both directions has been demonstrated in many species (see McRae, 1988). In the pig, some of the molecules may be digested in the lysosomal system, but the cells probably have the ability to transport intact macromolecules from the endometrial intercellular spaces to the uterine lumen and vice versa. The latter has been demonstrated for sheep (D. A. L. Shepherd \& H. W. J. Stroband, unpublished results) (Fig. 10) and cow (Guillomot et al., 1986).

\section{The ultrastructure of glandular epithelial cells}

The ultrastructure of the glandular compartment has been described by Perry \& Crombie (1982), Geisert et al. (1982a), Sidler et al. (1986) and Stroband et al. (1986). Under the influence of progesterone, the uterine glands start synthetic activity after Day 5 , as may be judged from the presence of Golgi cisternae and RER, and the storage of secretory vesicles $(0 \cdot 2-1 \cdot 5 \mu \mathrm{m})$ in the apical cytoplasm of the cells from Day 6 onwards (Fig. 8). No signs of secretion are seen at this stage, and the vesicles are filling up the apical part of the cells between Days 8 and 11. Around Day 11, embryonic signals lead to the abrupt release of the vesicles (Geisert et al., 1982a). In cyclic animals, this release takes place 1 or 2 days later and is less abrupt. A similar sudden release of gland products takes place in roe deer during blastocyst activation (Aitken, 1975). In the cow, many similar secretory vesicles are present at Day 7, but to a much lesser extent at Day 14 (Dahir 
et al., 1985). In the pig glycogen was found in increasing amounts from Day 5 onwards. In pregnant pigs this increase continued after Day 11, in contrast to cyclic pigs, in which it then decreased (Stroband et al., 1986).

\section{Embryo-maternal relationships}

\section{The pre-hatching period}

Delay in the oviduct. The embryos are retained within the oviduct for about 2 days. Eventually, rising progesterone concentrations seem to cause dilatation of the oviduct and, as a result, transport to the uterus (Dziuk, 1985). Retention in the oviduct gives the opportunity for modification of the uterine environment as many polymorphonuclear (phagocytotic) granulocytes pass through the uterine epithelium during oestrus (Stroband et al., 1986). Furthermore, the oviduct may secrete substances that affect cleavage rate (Fukui et al., 1988) or embryo viability (Gandolfi \& Moor, 1987), and change the composition of the zona pellucida (Hedrick et al., 1987). Broermann et al. (1988) found that the oviduct environment leads to a delay in the digestion of the zona pellucida and the function of the zona as a selective barrier may also be influenced.

The uterine environment modulates early embryonic development. Oestrogen and progesterone modulate the synthesis and secretion of uterine proteins (see Simmen et al., 1988). It is almost certain that the contribution of serum substances to the uterine environment is rapidly changing too, since the endometrial endothelium and epithelium function as a changing selective blooduterine lumen barrier (McRae, 1988). It appears obvious that the changing uterine environment will influence the timing of early development and the viability of embryos. However, little direct evidence is available for the pig. Furthermore, the potential for development up to the early blastocyst stage to be more or less independent of uterine factors, is a common feature in mammals. Mouse, rat and rabbit embryos will develop to blastocysts in vitro, and the same holds for the pig (Davis, 1985). However, even in the best culture media, long-term culture leads to developmental disorders, which may include delay in development, the contribution of fewer cells to a certain developmental stage, reduced viability after transfer, more variation in development and changes in metabolism (see Davis \& Day, 1978; Niemann et al., 1983; Papaioannou \& Ebert, 1988). Embryos also develop to blastocysts after restriction to the oviduct, although in the pig only the ampullary region can sustain the embryos (Pope \& Day, 1972). However, embryos retained in the ampulla developed at a slower rate than did embryos in the uterus. The low survival after transfer of pig embryos cultured for up to $27 \mathrm{~h}$ only compared to embryos transferred immediately shows that the loss of viability may occur rapidly in vitro (see review by Davis, 1985). This indicates the importance of the uterine environment and Allen \& Wright (1984) found a beneficial effect on pig embryo development of co-culture with endometrial monolayers. They found a similar effect using fibroblast monolayers, suggesting that cell to embryo contact improves embryonic development. The mammalian uterine fluid, including that of the pig, seems to contain factors that stimulate and factors that inhibit embryonic DNA synthesis (see Flint, 1981).

In the rabbit (Chang, 1950), the timing of entrance of the embryos into the uterus is critical, and the same may hold for other mammals. A uterine influence on the rate of early embryonic development was demonstrated in sheep and cow. Asynchronously transferred sheep embryos which are retarded in relation to the uterine environment will develop faster, while advanced embryos will develop more slowly (Wilmut et al., 1985). Garrett et al. (1988) found relatively early protein secretory activity in blastocysts from cows in which uterine secretions were advanced by progesterone injections. The existence, in many species (for example, roe deer: Aitken, 1975), of delayed implantation also illustrates the potency of the uterine environment to regulate embryonic growth.

Hardly any information about specific uterine proteins is available for the period before glandular secretion starts. The protein profiles continuously change during early pregnancy 


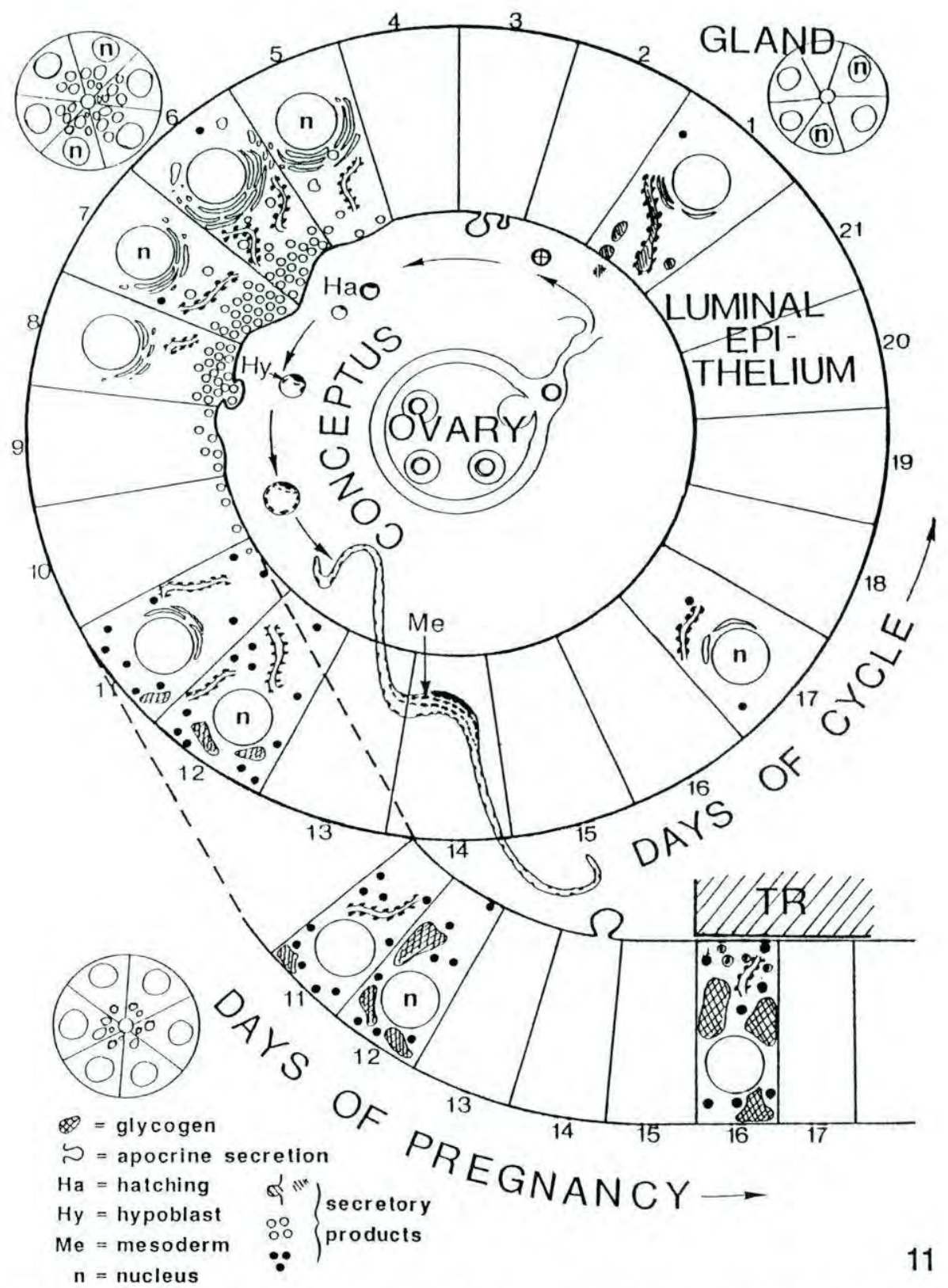

Fig. 11. Schematic drawing of the cytology of the uterine epithelium during the 21 days of the oestrous cycle and during early pregnancy. Some details of embryonic development are also given.

(Murray et al., 1972), and morphological evidence also suggests changing secretory products, but the factors influencing early development are unknown. Embryos may also change their own environment: steroids, concentrated in early embryos, may be delivered to the uterine environment and influence local vascular permeability and endometrial protein release (Flint, 1981); this is known to occur with oestrogens synthesized by the blastocysts later in early pregnancy (Geisert et al., 1982c). The concept of embryos not floating in a wide uterine lumen but restricted to a small 
'chamber' gives more credibility to considerations of the potential of young embryos to change their own uterine microenvironment.

\section{The period from hatching to attachment}

In the mouse, hatching may occur in vitro, but uterine oestrogen-dependent factors contribute to the efficiency and timing of the process (Chavez, 1984). The same may hold for the pig. However, at least after Day 11, several protease inhibitors are secreted by the uterine epithelium (Roberts \& Bazer, 1988). If these inhibitors are also secreted earlier, this would indicate the dominance of mechanical hatching mechanisms in pig.

Between hatching and attachment, development is less well supported by in-vitro systems than at earlier stages. The expansion and elongation of the blastocysts, possibly induced by ICM differentiation, are also dependent on uterine factors, since they do not occur in vitro. There is therefore considerable evidence for an interrelationship between embryos and uterus during this period.

Migration of the embryos from the tip of the uterine horn in the direction of the body of the uterus starts after hatching (Dhindsa et al., 1967), and takes place during hypoblast formation and blastocyst expansion. Oestrogens seem to play an important role, since Silastic beads are only transported through the uterine horns if they are impregnated with this steroid (Pope et al., 1982). Oestrogen secretion is measurable in blastocysts from 5-7 mm onwards, and increases rapidly during expansion and early elongation (Perry et al., 1976; Fischer et al., 1985). Migration seems to be the result of myometrial activity. Oestrogens might influence histamine release in the endometrium locally, which in turn could lead to increased blood flow through the myometrium and higher contractility of the muscle cells (Pope et al., 1982).

Embryonic oestrogens may also modulate uterine secretions, since exogenous oestrogens, given on Day 9, advance the uterine environment (Morgan et al., 1987a). In sheep, the presence of blastocysts leads to increased uterine protein secretion at Days 9 and 11, well before maternal recognition of pregnancy (Findlay et al., 1982). Macromolecules, present in the luminal fluid, may easily be absorbed by the trophoblast. It is possible that the secretion of the substance in the secretory vesicles within luminal epithelial cells plays some role in rapid blastocyst expansion, since both processes take place at the same time (Fig. 11). Furthermore, in sheep, the uterus has the ability to stimulate embryo development during this period (Wilmut et al., 1985).

As a result of asynchrony of uterus and blastocysts after oestrogen injection at Day 9, the blastocysts failed to survive to Day 16 (Morgan et al., 1987b). Other transfer experiments (Pope \& First, 1985; Morgan et al., 1987b, 1988) also point to detrimental effects of too early an exposure of embryos to oestrogen or, more likely, to the changed uterine environment. Possibly, a certain state of development must be reached before the induced uterine gland products become harmless to the embryos. It is also possible that oestrogens or the gland secretions cause the termination of the secretion of compounds, needed for normal embryo development during expansion, by the luminal epithelium. Uterine explants secrete fewer polypeptides after treatment of the sow with oestrogen at Day 9-10 (Gries et al., 1988).

Simmen et al. (1988) demonstrated a cell mitogen in uterine flushings at Day 10-12 as well as other growth factors. They suggested a function for this mitogen in epithelial and stromal cell growth, but the mitogen may also stimulate growth of embryos, including expansion and that part of elongation that depends on hyperplasia. As well as oestrogen, the elongating blastocyst produces prostaglandins (see Bazer \& First, 1983) and proteins (Godkin et al., 1982; Roberts et al., 1984). Between Days $10 \cdot 5$ and 12, mainly acidic, low-molecular weight proteins are secreted whereas during elongation a high molecular weight glycoprotein is secreted, and at Days 13-16 another major basic protein is produced. Embryonic proteins and prostaglandins may also be involved in the regulation of uterine secretory activity. Furthermore, the different embryonic secretion products may be involved in maternal recognition of pregnancy, which also takes place during the elongation process (for further details see Geisert et al., 1990). 

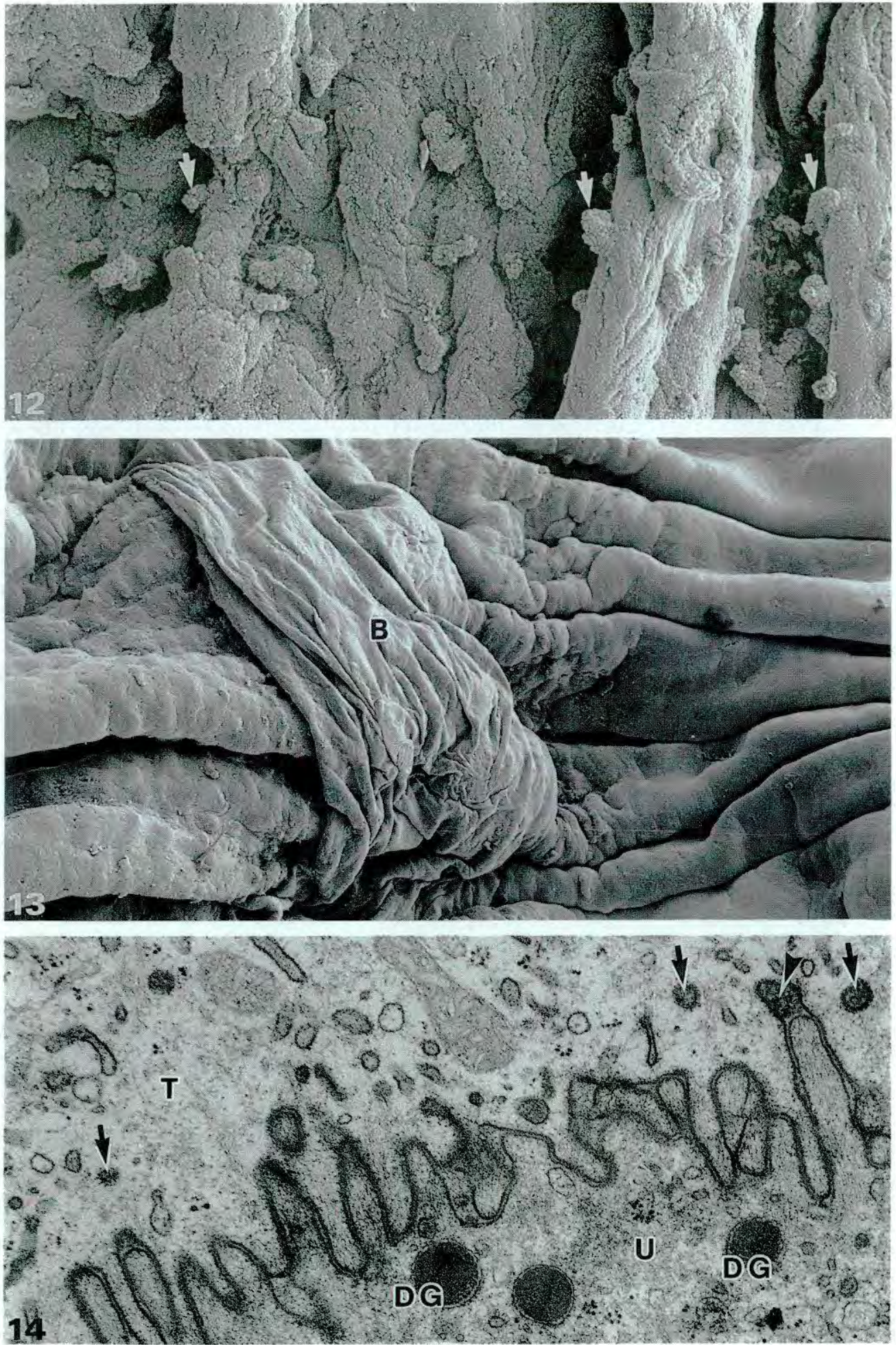


\section{Attachment}

Attachment (Figs 12-14) starts around Day 13-14 in the pig (Dantzer, 1985). It begins with loose contact between trophoblast and uterine membranes near the embryoblast, and is completed by intermingling of uterine and trophoblastic microvilli (Fig. 14) after Day 18 (Dantzer, 1985). The process gradually progresses to the tips of the blastocyst during the following days (King et al., 1982). True implantation, as seen in many other mammalian species, does not take place, although Day 10-16 blastocysts release plasminogen activator in vitro and plasminogen is present in the uterine lumen. However, endometrial secretion of a plasmin inhibitor also occurs (Fazleabas et al., 1983), which may be stimulated by embryonic oestrogen (Young et al., 1987). The uterus has a striking effect on trophectoderm morphology, preventing the formation of the syncytial trophoblast found in many other mammals. Transplantation to an ectopic site in the uterine wall results in the formation of a syncytium and signs of a process resembling implantation (Samuel \& Perry, 1972).

The presence of a conceptus induces local proliferations in the uterine luminal epithelium, resulting in the formation of knob-like extrusions (Fig. 12) which seem to anchor the conceptus to the mesometrial side of the uterus (Krzonkalla, 1979; Dantzer, 1985). Oestrogens may be important for the attachment process in the pig, as embryonic aromatase activity is high between Days 14 and 18 (Gadsby et al., 1980) and oestrogen production is high during attachment. Similarly, as discussed by Gadsby et al. (1980) implantation does not occur in rodents without ovarian oestrogens. Finally, oestrogen promotes the development of fenestrations in the endothelium of blood vessels in the implantation area in many species, including the pig (Keys \& King, 1988).

Changes in the composition of the trophoblast cell coat may be important for attachment in the ewe and other species (Guillomot et al., 1982). In the pig, lectin-binding characteristics of the blastocyst surface change just before attachment occurs (Whyte \& Robson, 1984). The glycocalyx of the uterine epithelium is reduced in thickness, probably by local activity of proteolytic enzymes, during initial attachment (Dantzer, 1985). Polypeptide secretion by the conceptus also changes before and during attachment (Godkin et al., 1982). The change from acidic protein dominance to mild basic protein dominance at the time of elongation and attachment (Van der Lende et al., 1988) may also contribute to the attachment process, possibly by masking of negative charges on cellular membranes.

In the pig, as in other domesticated ungulates, conceptuses are highly dependent on uterine secretions even after attachment (see Roberts et al., 1984). In our studies (Stroband et al., 1986) release of electron-dense granules, synthesized after Day 11 in the luminal epithelial cells, was not found until completion of attachment (Fig. 14).

\section{Conclusions}

Early pregnancy in ungulates is characterized by a preimplantation period that is prolonged after hatching. The concept of autonomous embryonic development may largely be correct for the

Figs 12-14. Attachment.

Fig. 12. SEM showing the formation of uterine epithelial proliferations (arrows) at the future attachment sites on Day 14. $\times 130$.

Fig. 13. SEM of an elongated blastocyst (B) overlying the uterine folds during attachment on Day $14 . \times 50$.

Fig. 14. TEM, Day 16. Attachment is completed in this area, as may be concluded from the interdigitation of uterine $(\mathrm{U})$ and trophoblastic $(\mathrm{T})$ microvilli. The uterine cells contain electron-dense secretory granules (DG) which appear to be secreted into the narrow space between uterus and embryo (arrowhead). Subsequently, the secretory substance is taken up by trophoblast cells by means of pinocytosis. Arrows point to pinocytotic vesicles. $\times 40000$. 


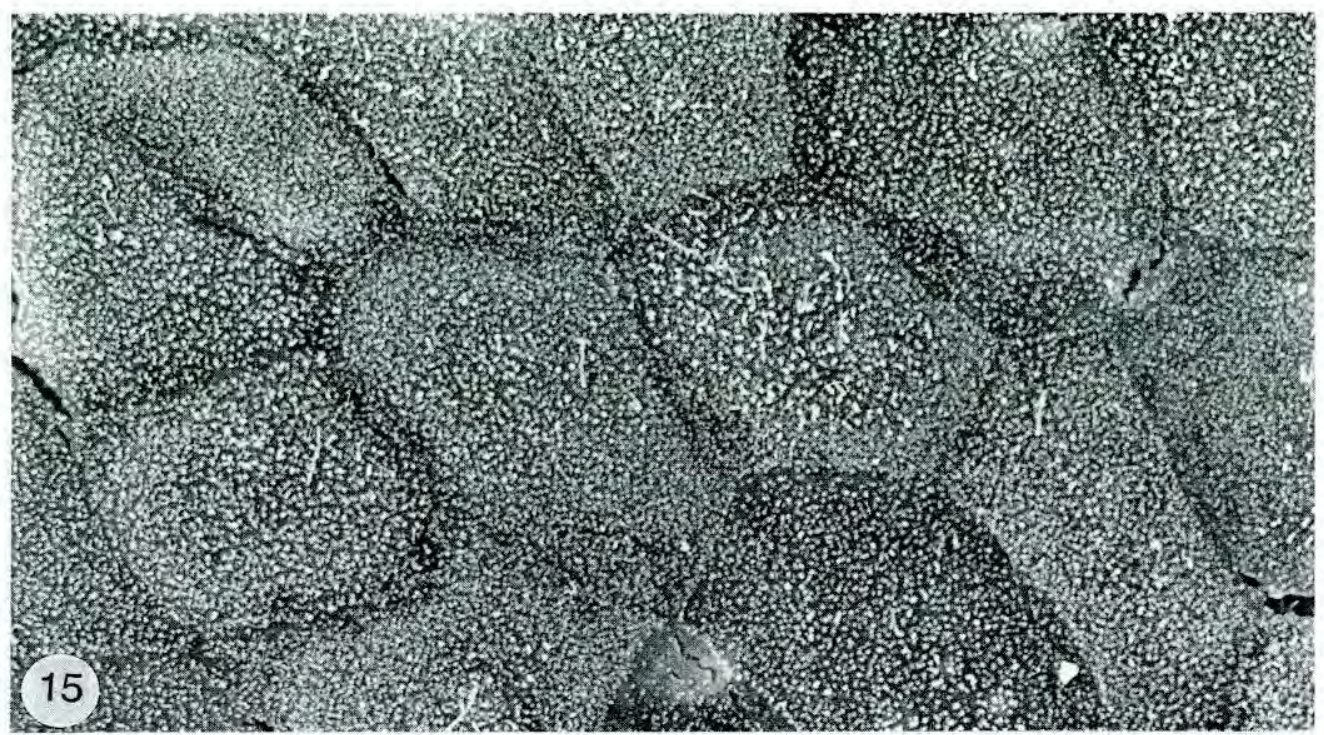

Fig. 15. SEM of Meishan pig uterine luminal epithelial cells in monolayer culture. $\times 14000$.

pre-hatching period, but the uterine environment has been shown to influence the morphology, viability and timing of development of embryos. Evidence is accumulating that, at least after hatching, conceptus-uterine interactions are significant. The histology and morphology of the preimplantation embryo, the cytology of the uterine epithelial cells, as well as the results of physiological and embryo transfer experiments, all indicate a close relationship between the embryos and the uterine tissues. Both contribute to a continuously changing uterine environment.

Important embryo-endometrium interactions often appear to follow after specific steps in embryo development. The morphology and the metabolism of the trophoblast, and, later, the hypoblast, may be regulated by the developing ICM. After the formation of the hypoblast, expansion of the blastocysts as well as their trans-uterine migration starts. Following the differentiation of the embryonic ectoderm, embryonic signals stimulate uterine gland secretion. The blastocysts subsequently elongate, and simultaneously differentiation of the third germ layer, the mesoderm, occurs. At the same time embryonic signals lead to maternal recognition of pregnancy and cause morphological changes in the uterine luminal epithelial cells leading to attachment. In each of these embryo-endometrium interactions embryonic oestrogens seem to be involved, but proteins and prostaglandins may also be important.

The within-litter variation in embryonic development is a problem in the study of embryomaternal relationships and the question arises as to which indicator best describes the developmental stage reached. In light of the above discussion, the differentiation of the ICM might give more information on the stage of development than the blastocyst diameter, which might be mainly related to trophoblast viability.

The study of embryo-maternal relationships is difficult in vivo, since the uterine environment is not necessarily similar to the embryonic (micro) environment, and cell-to-cell interactions are not easy to observe. Therefore, in-vitro systems should be developed to culture the different endometrial and embryonic components separately (Fig. 15) and in co-culture under well defined conditions. This will enable a causal analysis of preimplantation events.

We thank members of the Research Group on Early Pregnancy of the Agricultural University of Wageningen for their contributions; Birgitte van Rens, Christien Voolstra, Thys Leën and Nico Taverne for their help; and Mr H. G. Elerie (TFDL) for preparing the electron micrographs. 


\section{References}

Aitken, R.J. (1975) Ultrastructure of the blastocyst and endometrium of the roe deer (Capreolus capreolus) during delayed implantation. J. Anat. 119, 369-384.

Aitken, R.J. (1979) Uterine proteins. Oxford Rev. Reprod. Biol. 7, 351-382.

Albertini, D.F., Overström, E.W. \& Ebert, K.M. (1987) Changes in the organization of the actin cytoskeleton during preimplantation development of the pig embryo. Biol. Reprod. 37, 441-451.

Allen, R.L. \& Wright, R.W.J. (1984) In vitro development of porcine embryos in coculture with endometrial cell monolayers or culture supernatants. $J$. Anim. Sci. 59, 1657-1661.

Barends, P.M.G., Stroband, H.W.J., Taverne, N., te Kronnie, G., Leën, M.P.J.M. \& Blommers, P.C.J. (1989) Integrity of the preimplantation pig blastocyst during expansion and loss of polar trophoblast (Rauber cells) and the morphology of the embryo blast as an indicator for developmental stage. $J$. Reprod. Fert. 87, 715-726.

Bate, L.A. \& King, G.J. (1988) Production of oestrone and oestradiol-17 $\beta$ by different regions of the filamentous pig blastocyst. J. Reprod. Fert. 84, $163-169$.

Bazer, F.W. \& First, N.L. (1983) Pregnancy and parturition. J. Anim. Sci. 57 (suppl. 2), 425-460.

Beier, H.M. (1985) Proteins and steroids in early pregnancy. In Early Pregnancy Factors, pp. 1-11. Eds F. Ellendorff \& E. Koch. Perinatology Press, Ithaca.

Betteridge, K.J. \& Fléchon, J.E. (1988) The anatomy and physiology of preattachment bovine embryos. Theriogenology 29, 155-187.

Betteridge, K.J. \& Guillomot, M. (1982) Scanning microscopy of preattachment horse embryos. $J$. Reprod. Fert., Suppl. 32, 623, abstr.

Borland, R.M. (1977) Transport processes in the mammalian blastocyst. In Development in Mammals, vol. 1, pp. 31-68. Ed. M. H. Johnson. North Holland, Amsterdam.

Broermann, D.M., Xie, S., Nephew, K.P. \& Pope, W.F. (1988) Ability of the oviduct to delay enzymatic digestion of the zona pellucida. J. Anim. Sci. 66 (Suppl. 1), 416, abstr.

Calarco, P.G. \& McLaren, A. (1976) Ultrastructural observations of preimplantation stages of the sheep. $J$. Embryol. exp. Morph. 36, 609-622.

Carnegie, J.A., McCully, M.E. \& Robertson, H.A. (1985) The early development of the sheep trophoblast and the involvement of cell death. Am. J. Anat. 174, $471-488$.

Chang, M.C. (1950) Development and fate of transferred rabbit ova or blastocysts in relation to the ovulation time of recipients. J. exp. Zool. 114, 197-225.

Chavez, D.J. (1984) Cellular aspects of implantation. In Ultrastructure of Reproduction, pp. 247-259. Eds J. van Blerkom \& P. J. Motta. Martinus Nijhoff, The Hague.

Dahir, A.M., Hild, A., Weyrauch, K.D. \& Gehring, W. (1985) Zur Feinstruktur des Uterindrusen Epithels des Rindes. Z. mikrosk. Anat. Forsch., Leipzig 99, 303-320.
Dantzer, V. (1985) Electron microscopy of the initial stages of placentation in the pig. Anat. Embryol. 172, 281-293.

Davis, D.L. (1985) Culture and storage of pig embryos. $J$. Reprod. Fert., Suppl. 33, 115-124.

Davis, D.L. \& Day, B.N. (1978) Cleavage and blastocyst formation by pig eggs in vitro. J. Anim. Sci. 46, 1043-1053.

Dhindsa, D.S., Dziuk, P.J. \& Norton, H.W. (1967) Time of transuterine migration and distribution of embryos in the pig. Anat. Rec. 159, 325-330.

Ducibella, T. (1977) Surface changes of the developing trophoblast cells. In Development in Mammals, vol. 1, pp. 5-30. Ed. M. H. Johnson. North Holland, Amsterdam.

Dziuk, P.J. (1985) Effect of migration, distribution and spacing of pig embryos on pregnancy and fetal survival. J. Reprod. Fert., Suppl. 33, 57-63.

Ebert, K.M. \& Black, D.L. (1982) Effects of immunoglobulins on in vitro hatching of preimplantation rabbit embryos. J. Reprod. Immunol. 4, 39-51.

Enders, A. (1971) The fine structure of the blastocyst. In The Biology of the Blastocyst, pp. 71-93. Ed. R. J. Blandau. University of Chicago Press.

Enders, A.C. \& Schlafke, S.J. (1965) The fine structure of the blastocyst: some comparative studies. In Preimplantation Stages of Pregnancy (Ciba Fdn Symp. No. 87), pp. 29-54. Eds G. E. W. Wolstenholme \& M. O'Connor. J. \& A. Churchill, London.

Enders, A.C., Lantz, K.C., Liu, I.K.M. \& Schlafke, S. (1988) Loss of polar trophoblast during differentiation of the blastocyst of the horse. J. Reprod. Fert. 83, $447-460$.

Fazleabas, A.T., Geisert, R.D., Bazer, F.W. \& Roberts, R.M. (1983) Relationship between release of plasminogen activator and estrogen by blastocysts and secretion of plasmin inhibitor by uterine endometrium in the pregnant pig. Biol. Reprod. 29, $225-238$.

Fazleabas, A.T., Bazer, F.W., Hansen, P.J., Geisert, R.D. \& Roberts, R.M. (1985) Differential patterns of secretory protein localization within the pig uterine endometrium. Endocrinology 116, 240-245.

Findlay, J.K., Clarke, I.J., Swaney, J., Calvin, N. \& Doughton, B. (1982) Oestrogen receptors and protein synthesis in caruncular and intercaruncular endometrium of sheep before implantation. J. Reprod. Fert. 64, 329-339.

Fischer, H.E., Bazer, F.W. \& Fields, M.J. (1985) Steroid metabolism by endometrial and conceptus tissues during early pregnancy and pseudopregnancy in gilts. J. Reprod. Fert. 75, 69-78.

Fléchon, J-E., Guillomot, M., Charlier, M., Fléchon, B. \& Martal, J. (1986) Experimental studies on the elongation of the ewe blastocyst. Reprod. Nutr. Develop. 26, 1017-1024.

Fleming, T.P. \& Goodall, H. (1986) Endocytic traffic in trophectoderm and polarized blastomeres of the mouse preimplantation embryo. Anat. Rec. 216, 490-503.

Flint, A.P.F. (1981) A unifying hypothesis for the control of blastocyst growth based on observations on the pig. J. Reprod. Fert., Suppl. 29, 215-227. 
Flood, P.F., Betteridge, K.J. \& Diocee, M.S. (1982) Transmission electron microscopy of horse embryos 3-16 days after ovulation. J. Reprod. Fert., Suppl. 32, 319-327.

Freitag, M., Dopke, H.H., Niemann, H. \& Elsaesser, F. (1988) Ontogeny of RNA synthesis in preimplantation pig embryos and the effect of antioestrogen on blastocyst formation in vitro. J. Reprod. Fert. Abstr. Series 1, 11, abstr.

Fukui, Y., Glew, A.M., Gandolfi, F. \& Moor, R.M. (1988) In vitro culture of sheep oocytes matured and fertilized in vitro. Theriogenology 29, 883-891.

Gadsby, J.E., Heap, R.B. \& Burton, R.D. (1980) Oestrogen production by blastocyst and early embryonic tissue of various species. J. Reprod. Fert. 60, $409-417$.

Gandolfi, F. \& Moor, R.M. (1987) Stimulation of early embryonic development in the sheep by coculture with oviduct epithelial cells. J. Reprod. Fert. 81, 23-28.

Garrett, J.E., Geisert, R.D., Zavy, M.T. \& Morgan, G.L. (1988) Evidence for early regulation of conceptus growth and development in beef cattle. J. Reprod. Fert. 84, 437-446.

Geisert, R.D., Renegar, R.H., Thatcher, W.W., Roberts, R.M. \& Bazer, F.W. (1982a) Establishment of pregnancy in the pig: I. Interrelationships between preimplantation development of the pig blastocyst and uterine endometrial secretions. Biol. Reprod. 27, 925-939.

Geisert, R.D., Brookbank, J.W., Roberts, R.M. \& Bazer, F.W. (1982b) Establishment of pregnancy in the pig: II. Cellular remodelling of the porcine blastocyst during elongation on Day 12 of pregnancy. Biol. Reprod. 27, 941-955.

Geisert, R.D., Thatcher, W.W., Roberts, R.M. \& Bazer, F.W. (1982c) Establishment of pregnancy in the pig: III. Endometrial secretory response to estradiol valerate administered on Day 11 of the estrous cycle. Biol. Reprod. 27, 957-965.

Geisert, R.D., Zavy, M.T., Moffatt, R.J., Blair, R.M. \& Yellin, T. (1990) Embryonic steroids and the establishment of pregnancy in pigs. J. Reprod. Fert., Suppl. 40, 293-305.

Godkin, J.D., Bazer, F.W., Lewis, G.S., Geisert, R.D. \& Roberts, R.M. (1982) Synthesis and release of polypeptides by pig conceptuses during the period of blastocyst elongation and attachment. Biol. Reprod. 27, 977-987.

Gries, L.K., Geisert, R.D., Zavy, M.T., Garrett, J.E. \& Morgan, G.L. (1988) Uterine secretory alterations coincident with embryonic mortality in the gilt after exogenous estrogen administration. J. Anim. Sci. 67, $276-284$.

Guillomot, M., Fléchon, J.E. \& Wintenberger-Torrès, S. (1982) Cytochemical studies of uterine and trophoblast surface coats during blastocyst attachment in the ewe. J. Reprod. Fert. 65, 1-8.

Guillomot, M., Betteridge, K.J., Harvey, D. \& Goff, A.K. (1986) Endocytotic activity in the endometrium during conceptus attachment in the cow. J. Reprod. Fert. 78, 27-36.

Hastings, R.A. \& Enders, A.C. (1974) Uptake of exogenous protein by the preimplantation rabbit. Anat. Rec. 179, 311-330.

Hedrick, J.L., Wardrip, N.J. \& Berger, T. (1987) Differences in the macromolecular composition of the zona pellucida isolated from pig oocytes, eggs, and zygotes. J. exp. Zool. 241, 257-262.

Hunter, R.H.F. (1974) Chronological and cytological details of fertilization and early embryonic development in the domestic pig, Sus scrofa. Anat. Rec. 178, 169-186.

Hyttel, P. (1985) The epithelium of uterine biopsies from cyclic dairy cattle: ultrastructure and endocytotic activity. Acta anat. 123, 93-100.

Johnson, M.H. (1981) The molecular and cellular basis of preimplantation mouse development. Biol. Rev. 56, 463-498.

Johnson, S.A., Morgan, G. \& Wooding, F.B.P. (1988) Alterations in uterine epithelial tight junction structure during the oestrous cycle and implantation in the pig. J. Reprod. Fert. 83, 915-922.

Keys, J.L. \& King, G.J. (1988) Morphological evidence for increased uterine vascular permeability at the time of embryonic attachment in the pig. Biol. Reprod. 39, 473- 487.

King, G.J. \& Ackerley, C.A. (1985) Demonstration of oestrogens in developing pig trophectoderm and yolk sac endoderm between Days 10 and 16. J. Reprod. Fert. 73, 361-367.

King, G.J., Atkinson, B.A. \& Robertson, H.A. (1982) Implantation and early placentation in domestic ungulates. J. Reprod. Fert., Suppl. 31, 17-30.

King, W.A., Nair, A., Chartrain, I. \& Betteridge, K.J. (1988) Nucleolus organizer regions and nucleoli in preattachment bovine embryos. J. Reprod. Fert. 82, 87-95.

Krzonkalla, C. (1979) Das Epithel der Uterusschleimhaut des Schweines wahrend der Implantation. Ph.D. thesis, University of Munchen.

Marrable, A.W. (1971) The Embryonic Pig. Pitman \& Sons, London.

Massip, A., Mulnard, J., Huygens, R., Hanzen, C., Van der Zwalmen, P. \& Ectors, F. (1981) Ultrastructure of the cow blastocyst. J. Submicrosc. Cytol. 13, 31-40.

McLaren, A. \& Smith, R. (1977) Functional test of tight junctions in the mouse blastocyst. Nature, Lond. 267, $351-353$.

McRae, A. (1988) The blood-uterine lumen barrier and exchange between extracellular fluids. J. Reprod. Fert. 82, 857-873.

Morgan, G.L., Geisert, R.D., Zavy, M.T., Shawley, R.V. \& Fazleabas, A.T. (1987a) Development of pig blastocysts in a uterine environment advanced by exogenous oestrogen. J. Reprod. Fert. 80, 125-131.

Morgan, G.L., Geisert, R.D., Zavy, M.T. \& Fazleabas, A.T. (1987b) Development and survival of pig blastocysts after oestrogen administration on Day 9 or Days 9 and 10 of pregnancy. J. Reprod. Fert. 80, 133-141.

Morgan, G.L., Geisert, R.D., Gries, L.K. \& Zavy, M.T. (1988) Effect of asynchronous transfer and estrogen administration on survival and development of porcine embryos. J. Anim. Sci. 66 (Suppl. 1), 423, abstr.

Murray, M.K., Bazer, F.W., Wallace, H.D. \& Warnick, A.C. (1972) Quantitative and qualitative variation in the secretion of protein by the porcine uterus during the estrous cycle. Biol. Reprod. 7, 314-320. 
Niemann, H. \& Elsaesser, F. (1986) Evidence for estrogen dependent blastocyst formation in the pig. Biol. Reprod. 35, 10-16.

Niemann, H., Illera, M.J. \& Dziuk, P.J. (1983) Developmental capacity, size and number of nuclei in pig embryos cultured in vitro. Anim. Reprod. Sci. 5, $311-322$.

Norberg, H.S. (1973a) Ultrastructural aspects of the preattached pig embryo: cleavage and early blastocyst stages. Z. Anat. Entwickl. Gesch. 143, 95-114.

Norberg, H.S. (1973b) Ultrastructure of pig tubal ova. The unfertilized and pronuclear stage. Z. Zellforsch. mikrosk. Anat. 141, 103-122.

Oxenreider, S.L. \& Day, B.N. (1965) Transport and cleavage of ova in swine. J. Anim. Sci. 24, 413 417.

Papaioannou, V.E. \& Ebert, K.M. (1988) The preimplantation pig embryo: cell number and allocation to trophectoderm and inner cell mass of the blastocyst in vivo and in vitro. Development 102, 793-803.

Paria, B.C., Sengupta, J. \& Manchanda, S.K. (1984) Role of embryonic oestrogen in rabbit blastocyst development and metabolism. J. Reprod. Fert. 70, 429436

Patten, B.M. (1948) Embryology of the Pig. McGrawHill, New York.

Perry, J.S. \& Crombie, P.R. (1982) Ultrastructure of the uterine glands of the pig. J. Anat. 134, 339-350.

Perry, J.S., Heap, R.B., Burton, R.D. \& Gadsby, J.E. (1976) Endocrinology of the blastocyst and its role in the establishment of pregnancy. J. Reprod. Fert, Suppl. 25, 85-104.

Polge, C. (1982) Embryo transplantation and preservation. In Control of Pig Reproduction, pp. 277-291. Eds D. J. A. Cole \& G. R. Foxcroft. Butterworth, London.

Pope, C.E. \& Day, B.N. (1972) Development of pig embryos following restriction to the ampullar portion of the oviduct. J. Reprod. Fert. 31, 135-138.

Pope, W.F. \& First, N.L. (1985) Factors affecting the survival of pig embryos. Theriogenology 23, 91-105.

Pope, W.F., Maurer, R.R. \& Stormshak, F. (1982) Intra uterine migration of the porcine embryo: influence of estradiol 17- $\beta$ and histamine. Biol. Reprod. 27, 575-579.

Prather, R.S. \& First, N.L. (1988) A review of early mouse embryogenesis and its application to domestic species. J. Anim. Sci. 66, 2626-2635.

Roberts, R.M. \& Bazer, F.W. (1988) The function of uterine secretions. J. Reprod. Fert. 82, 875-892.

Roberts, R.M., Bazer, F.W. \& Thatcher, W.W. (1984) Biochemical interactions between blastocyst and endometrium in the large domestic animals. J. Biosci. 6 (Suppl. 2), 63-74.
Samuel, C.A. \& Perry, J.S. (1972) The ultrastructure of pig trophoblast transplanted to an ectopic site in the uterine wall. J. Anat. 113, 139-149.

Sidler, X., Zimmermann, W. \& Leiser, R. (1986) Das normale zyklische Geschehen im Endometrium des Schweines. University of Bern, Bern.

Simmen, R.C.M., Ko, Y., Liu, X.H., Wilde, M.H., Pope, W.F. \& Simmen, F.A. (1988) A uterine cell mitogen distinct from epidermal growth factor in porcine uterine luminal fluids: characterization and partial purification. Biol. Reprod. 38, 551-561.

Stone, B.A., Seamark, R.F., Kelly, R.W. \& Deam, S. (1986) Production of steroids and release of prostaglandins by spherical pig blastocysts in vitro. Aust. J. biol. Sci. 39, 283-294.

Stroband, H.W.J., Taverne, N. \& Van den Bogaard, M. (1984) The pig blastocyst: its ultrastructure and the absorption of protein macromolecules. Cell Tiss. Res. 235, 347-356.

Stroband, H.W.J., Taverne, N., Langenfeld, K. \& Barends, P.M.G. (1986) The ultrastructure of the uterine epithelium of the pig during the estrous cycle and early pregnancy. Cell Tiss. Res. 246, 81-89.

Szollosi, D. \& Hunter, R.H.F. (1973) Ultrastructural aspects of fertilization in the domestic pig: sperm penetration and pronuclear formation. J. Anat. 116, 181-206.

Van der Lende, T., Hazeleger, W., Soede, N.M. \& Stroband, H.W.J. (1988) Reversal of anionic protein dominance to cationic protein dominance in uterine secretions at the time of elongation and attachment of the conceptus in gilts. J. Reprod. Fert. Abstr. Series 1, 23, abstr.

Whyte, A. \& Robson, T. (1984) Saccharides localized by fluorescent lectins on trophectoderm and endometrium prior to implantation in pigs, sheep and equids. Placenta 5, 533-540.

Wilmut, I., Sales, D.I. \& Ashworth, C.J. (1985) The influence of variation in embryo stage and maternal hormone profiles on embryo survival in farm animals. Theriogenology 23, 107-119.

Wintenberger-Torrès, S. \& Fléchon, J.E. (1974) Ultrastructural evolution of the trophoblast cells of the preimplantation sheep blastocyst from day 8 to day 18. J. Anat. 118, 143-153.

Wright, R.W., Grammer, J., Bondioli, K., Kuzan, F. \& Menino, A. (1983) Protein content and volume of early porcine blastocysts. Anim. Reprod. Sci. 5, 207-212.

Young, K.H., Bazer, F.W., Simpkins, J.W. \& Roberts, R.M. (1987) Effects of early pregnancy and acute $17-\beta$ estradiol administration on porcine uterine secretion, cyclic nucleotides, and catecholamines. Endocrinology 120, 254-262. 